Davor Lučić · Jakica Njire • Mira Morović • Robert Precali $\cdot$ Dragica Fuks $\cdot$ Jakša Bolotin

\title{
Microzooplankton in the open waters of the northern Adriatic Sea from 1990 to 1993: the importance of copepod nauplit densities
}

Received: 22 July 2002 / Revised: 6 January 2003 / Accepted: 7 January 2003 / Published online: 14 February 2003 (C) Springer-Verlag and AWI 2003

\begin{abstract}
Zooplankton was sampled during 39 cruises, from 1990 to 1993 , at four fixed stations in the open northern Adriatic. Hydrographic factors were important in determining the abundance of the smallest and largest components of the northern Adriatic food chain during this period. Nauplii - especially those of the smallest size fractions - were the major mediators of material transfer between primary producers and higher trophic levels. There was a significant difference in the vertical distribution of nauplii size fractions between the eastern and western parts of the northern Adriatic, but not in their population density. According to multiple correlation analyses, the abundance of naupliar size fractions in the western area correlated strongly with temperature and with certain biological factors. This study confirms the important influence of the Po River and of mid-Adriatic waters on the planktonic ecosystem of the northern Adriatic.
\end{abstract}

Keywords Microzooplankton - Nauplii size fraction · Po River discharge $\cdot$ Adriatic Sea

\section{Introduction}

The northern Adriatic is a productive and typically neritic sea (Benović et al. 1984) with generally cyclonic circulation and periodic inflow of oligotrophic water from the southern and central Adriatic (Orlić et al. 1992). Hydrographic conditions vary owing to shallow depth,

Communicated by H.-D. Franke

D. Lučić $(\bowtie) \cdot$ J. Njire · M. Morović · J. Bolotin

Laboratories Dubrovnik,

Institute of Oceanography and Fisheries,

D. Jude 12, 20000 Dubrovnik, Croatia

e-mail: lucic@labdu.izor.hr

Tel.: +385-20-323449

Fax: $+385-20-323872$

R. Precali · D. Fuks

Center for Marine Research, Rudjer Bošković Institute,

52210 Rovinj, Croatia high fresh water runoff (primarily from the Po River), and the region's fluctuating climate (Boicourt et al. 1999). The area appears to be especially sensitive to seasonal and long-term variations in nutrient load, the impact of which depends significantly on changes in the oceanographic conditions that have their origin in climatic fluctuations (Degobbis et al. 2000). In fact, this ecosystem has recently been exposed to strong environmental stress, as manifested by the periodic presence of mucous aggregates (Ott and Herndl 1995; Cosović and Vojvodić 2000), large-scale hypoxic and anoxic events, and decreased biodiversity (Benović et al. 2000).

Copepod nauplii are a major component of zooplankton biomass throughout the year in many marine ecosystems (Calbet et al. 2001), even though their contribution to total zooplankton abundance in some cases is less than 5\% (Park and Marshall 2000). Despite a long tradition of microzooplankton research in the northern Adriatic (see Coats and Revelante 1999), there have been surprisingly few investigations of the resident copepod populations throughout all developmental stages (Kršinić 1995; Gotsis-Skretas et al. 2000). In particular, the contribution of nauplii to secondary production has received little attention. With weight-specific ingestion rates three to four times higher than those of adults (Lonsdale et al. 1996), they may be expected to play an important role in the food web.

Owing to their small size, abundance, and ability to feed on pico/nano-sized particles, copepod nauplii are critical intermediaries between 'classical' and microbial food webs (Roff et al. 1995). Prey size strongly influences the feeding success of fish larvae (Hunter 1984). Furthermore, as copepod nauplii are the major prey of a number of commercially important fish species (Last 1980; Incze et al. 1996), the size structure of nauplii populations can be expected to influence larval fish survival and subsequent recruitment to adult stocks. For example, one of the more intensively exploited fish in the northern Adriatic, the anchovy Engraulis encrasicolus, depends critically upon nauplii during its transition 
between passive and active feeding (Regner 1985; Coombs et al. 1997; Conway et al. 1998).

The present study reports data on the relative abundance and distribution of different size fractions of nauplii in the northern Adriatic. These data are related to key environmental variables, and to pico-, nano-, and microphytoplankton production.

\section{Methods}

Samples were taken at four fixed stations (see Fig. 1), two in the western part of the northern Adriatic (WNA: SJ101, SJ198), and two in the eastern part (ENA: ZI012, ZI052), aboard Vila Velebita of the Center for Marine Research in Rovinj, Croatia. Nine cruises were conducted in 1990, six in 1991, and 12 each in 1992 and 1993. Water was collected with a 5-liter Niskin bottle at $0.3,10$, and $20 \mathrm{~m}$, and also near the bottom. Samples were fixed in $2 \%$ formalin neutralized with $\mathrm{CaCO}_{3}$.

Temperature was measured with a reversing thermometer, and salinity with a Yeo-Kal MkII salinometer. The average annual temperature and salinity models were based on 1966-2000 daily values, and on records of Po River discharge from 1917 to 2000. Models were calculated using the least-squares method, fitting a sinusoidal function with the first six harmonics. Data from station SJ107 were used to analyze long-term variations in salinity, mainly because consistent measurements have been performed at that station since 1966 (Fig. 1).

Samples $(20 \mathrm{ml})$ from each Niskin bottle were taken for analyses of heterotrophic bacteria and cyanobacteria abundance and passed through a $0.2 \mu \mathrm{m}$ filter, and concentrated to $2 \%(\mathrm{v} / \mathrm{v})$. Within 3 weeks of sampling, picoplankton abundance was determined by epifluorescence microscopy (Nikon Microphot-SA microscope). Heterotrophic bacteria density was determined using the DAPI (4,6-diamidino-2-phenylindol) staining method (Porter and Feig 1980) and filtering onto black polycarbonate filters (pore size $0.2 \mu \mathrm{m}$ ). Bacteria were counted using UV light excitation $(330-380 \mathrm{~nm})$. Cyanobacteria were counted using green light excitation $(510-560 \mathrm{~nm})$ after $15 \mathrm{ml}$ sample filtration onto black polycarbonate filters (pore size $0.6 \mu \mathrm{m}$; Takahashi et al. 1985). At least ten fields, or 500 picoplankton cells, were counted per sample.

Chlorophyll $a$ concentrations (Chl- $a$ ) were analyzed fluorometrically using standard methods (Strickland and Parsons 1972). Measurements were performed on a TD-700 fluorometer. Phytoplankton cell numbers were counted using an inverted microscope.

Microzooplankton samples were sedimented for $72 \mathrm{~h}$, until the original volume of 51 was reduced to $3 \mathrm{ml}$. The organisms were counted with a Wild stereomicroscope at magnifications of $100 \times$ and 400x. Owing to naupliar size differences, samples were divided into five categories: NS1 $(<80 \mu \mathrm{m})$, NS2 $(80-120 \mu \mathrm{m}), \mathrm{NS} 3(120$ $160 \mu \mathrm{m})$, NS4 $(160-200 \mu \mathrm{m})$, and NS5 (>200 $\mu \mathrm{m})$.

Mesozooplankton and anchovy eggs were collected by bottomto-surface vertical tows with a $250 \mu \mathrm{m}$ mesh Nansen plankton net (diameter $80 \mathrm{~cm}$ ) and were examined under a stereomicroscope.

In all text, figures, and tables in this article, reference to 'surface layer' means depths between 0.3 and $10 \mathrm{~m}$; 'bottom layer' is used for depths between $20 \mathrm{~m}$ and the bottom.

The Mann-Whitney $U$ test (Zar 1974) was used to compare the differences in Chl- $a$, bacteria, cyanobacteria, phytoplankton abundance, and nauplii density between western (WNA) and eastern (ENA) stations, and between surface and bottom layers.

Linear correlation coefficients, multiple correlation coefficients, and regression coefficients between nauplii fractions and abiotic as well as other biotic factors were calculated. Discussion of results is based on the interpretation of statistical methods by Waugh (1952) and Spiegel (1972).

In all statistical tests, data from August 1991 were not included, because of the appearance of a large amount of mucous aggregates and the subsequent decrease in numbers of micrometazoans (Kršinić 1995), especially in nauplii.

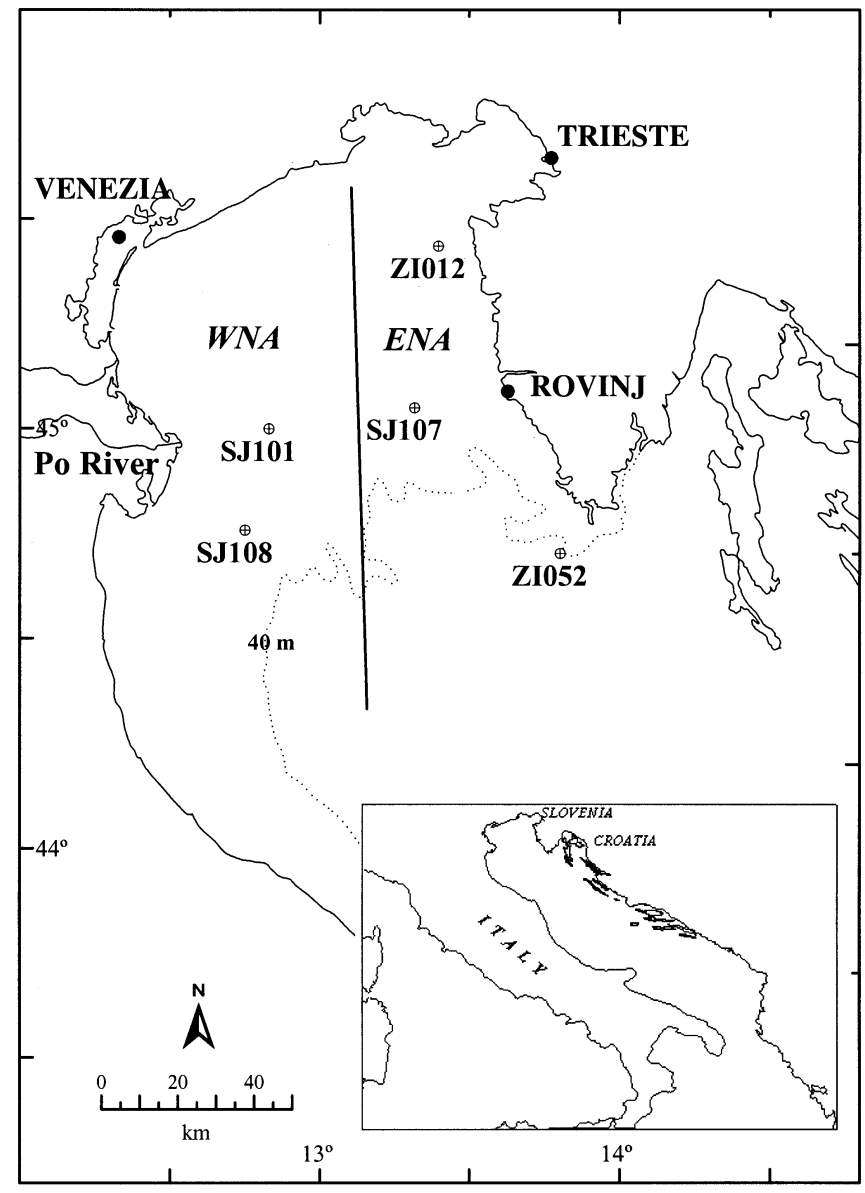

Fig. 1 Map of sampling stations in the northern Adriatic Sea. Line separates western (WNA) and eastern (ENA) parts of the sampling area

\section{Results}

\section{Hydrographic conditions}

Thermal stratification of the water column began as early as May, and the thermocline was typically formed by early summer. During autumn, the vertical gradient weakened and a moderate temperature inversion occurred. The water column was generally isothermal in winter. Temperature ranged from 7.40 to $28.93^{\circ} \mathrm{C}$ (mean $15.60 \pm 5.45^{\circ} \mathrm{C}$ ) at WNA, and from 8.86 to $28.24^{\circ} \mathrm{C}$ (mean $17.49 \pm 4.86^{\circ} \mathrm{C}$ ) at ENA.

The hydrographic situation during 1990-1993 was characterized by higher-than-average salinity in the whole area of investigation. During this period, salinity ranged from 21.89 to 38.49 (mean 36.65 \pm 2.18 ) in WNA, and from 34.41 to 38.52 (mean $37.68 \pm 0.70$ ) in ENA. The average monthly difference from the model (Fig. 2) in the upper $10 \mathrm{~m}$ of the water column showed that, for most of the year, salinity was above average. This difference was especially marked during spring, owing to lower-thannormal freshwater input. During this period the Po River, the area's main freshwater source, discharged 200- 
Fig. 2 Average monthly deviation of salinity $(\Delta s)$ from the annual model (1966-2000) for surface and $10 \mathrm{~m}$ depth in western $(W N A)$ and eastern (ENA) parts of sampling area during the period 1990-1993. Average monthly deviation of Po river flow $\left(\Delta Q_{m}\right)$ from the annual model (1966-2000)

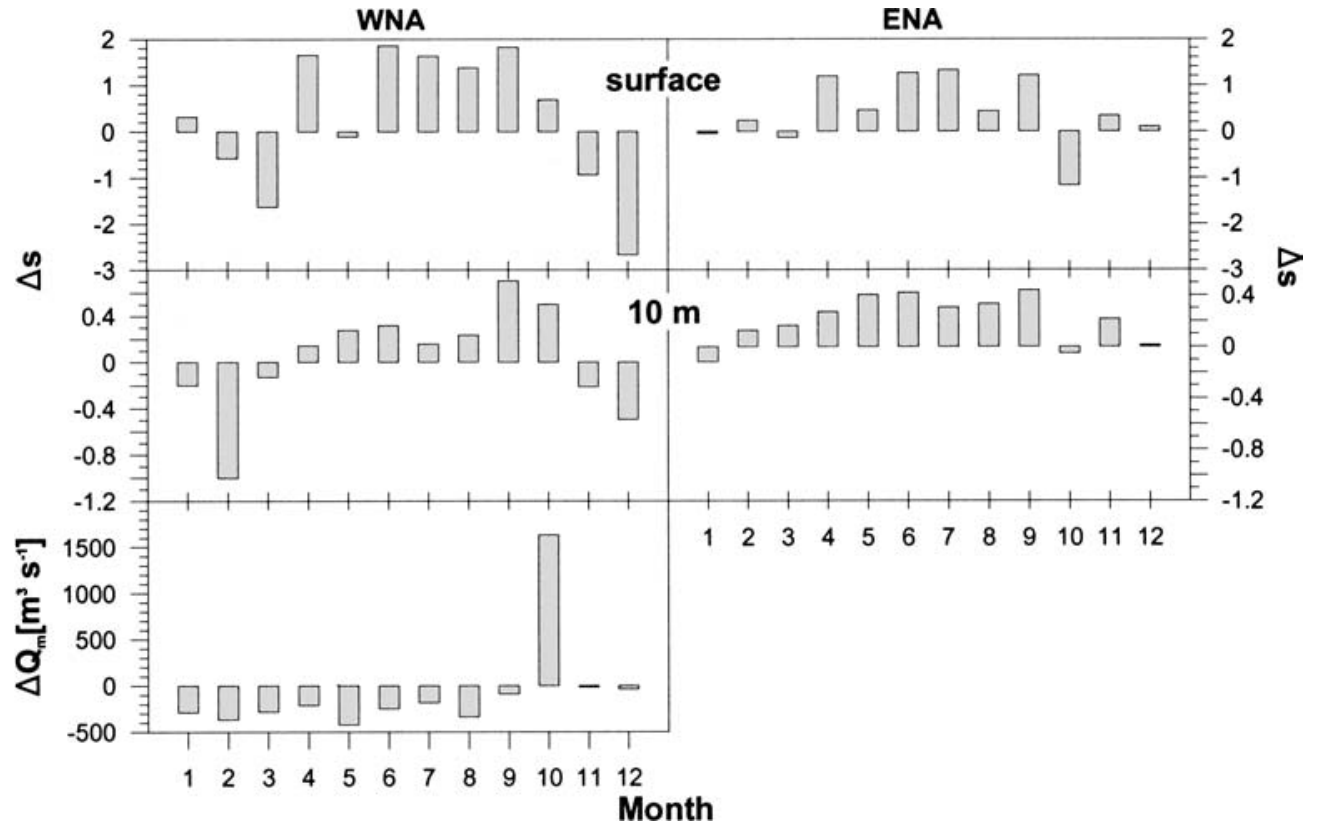

$400 \mathrm{~m}^{3} \mathrm{~s}^{-1}$ (Fig. 2) less than the average $\left(1,500 \mathrm{~m}^{3} \mathrm{~s}^{-1}\right)$. The sole exception was in October when the flow was $1,700 \mathrm{~m}^{3} \mathrm{~s}^{-1}$.

Biotic parameters

\section{Picoplankton}

There was an evident horizontal gradient in bacteria abundance over the entire area, from WNA to ENA. This started after the spring bloom and lasted until the late fall phytoplankton bloom (Fig. 3).

A maximum of $5,642 \times 10^{6}$ cells $1^{-1}$ was recorded at WNA in May 1992. High abundances $\left(>5,000 \times 10^{6}\right.$ cells $1^{-1}$ ) were noted in August 1992 and October 1993. The

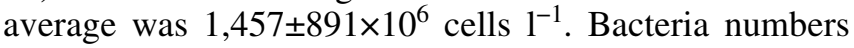
were considerably lower at ENA. A pronounced maximum of $3,297 \times 10^{6}$ cells $1^{-1}$ was found in November,

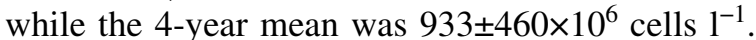

Cyanobacteria occurred in particularly high numbers throughout the summer and, at WNA, at an extremely high level in July 1991: $1,008 \times 10^{6}$ cells $1^{-1}$ (Fig. 4). Average abundance, however, was only $53 \pm 104 \times 10^{6} \mathrm{l}^{-1}$, while at ENA the 4 -year average was $33 \pm 31 \times 10^{6}$ cells $^{-1}{ }^{1}$.

\section{Phytoplankton}

High Chl- $a$ concentrations and high cell counts were recorded at WNA during spring and fall. The Chl- $a$ maximum, $13.03 \mathrm{mg} \mathrm{m}^{-3}$, was found in October 1993 (Fig. 5). The 4-year Chl- $a$ average was $1.34 \pm 1.82 \mathrm{mg} \mathrm{m}^{-3}$. Increased Chl- $a$ concentrations were registered at ENA only in fall. The maximum, $3.20 \mathrm{mg} \mathrm{m}^{-3}$, was also found in October, with a 4-year mean of $0.39 \pm 0.43 \mathrm{mg} \mathrm{m}^{-3}$. In
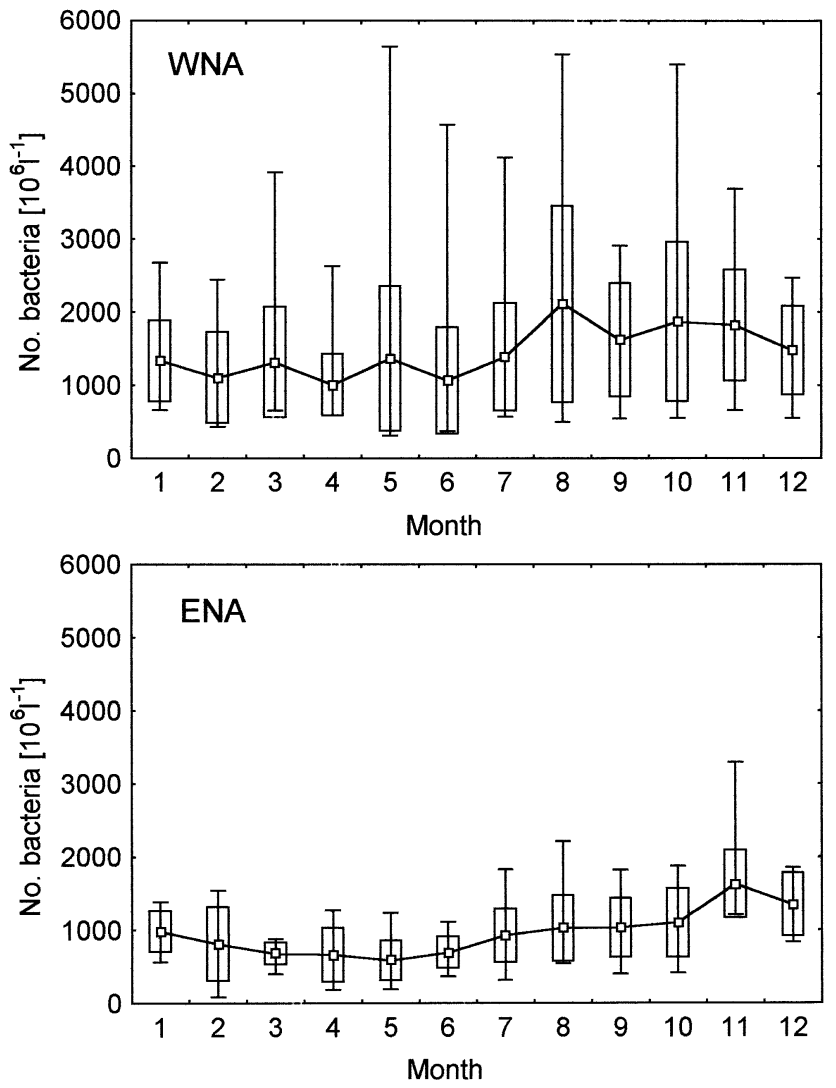

Fig. 3 Box plot of numerical abundance of bacteria in the northern Adriatic Sea during 1990-1993. Middle tiny squares and line indicate mean values, box presents standard deviations, whisker min-max values 

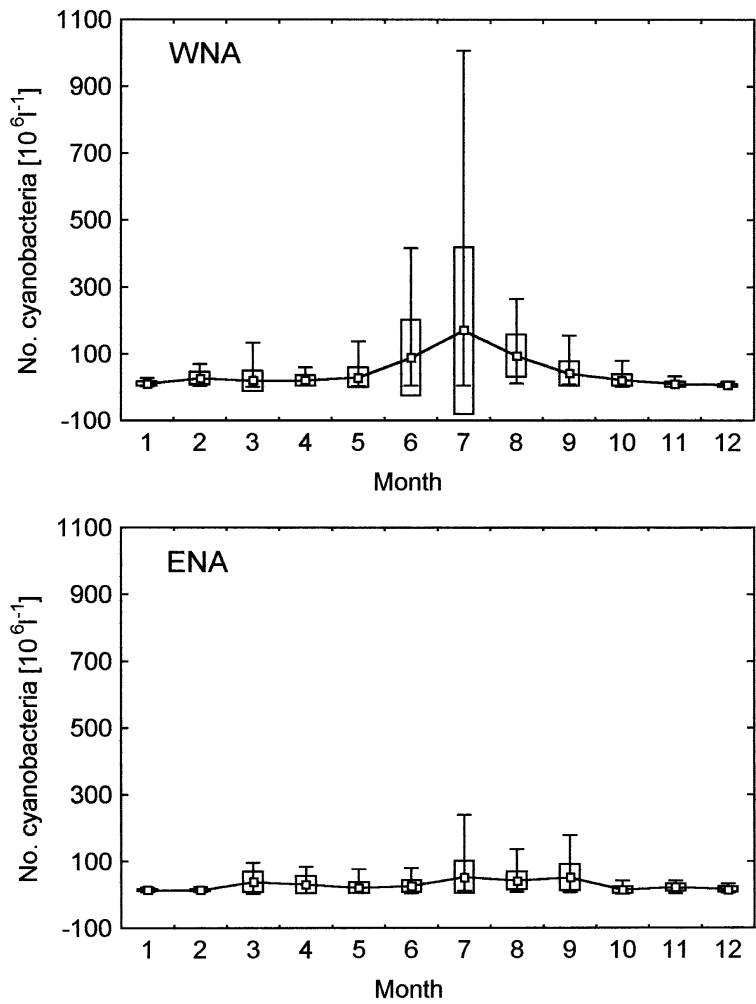

Fig. 4 Box plot of the numerical abundances of cyanobacteria in the northern Adriatic Sea during 1990-1993. Middle tiny squares and line indicate mean values, box presents standard deviations, whisker min-max values

both areas, the lowest mean values were noted during summer.

Nanophytoplankton occurred in especially high numbers at WNA throughout most of the year (Fig. 6). The average abundance of total nanophytoplankton was $2.28 \pm 3.84 \times 10^{6}$ cells $1^{-1}$, with a maximum of $49.68 \times 10^{6}$ cells $1^{-1}$ in May 1990. Lower values were noted at the end of the summer and at the beginning of fall, quite the opposite of Chl- $a$ concentrations during this period. Densities were lower at ENA, with a maximum of $7.93 \times 10^{6}$ cells $1^{-1}$ in June 1991 , and with the same minimum as in the western area. The 4-year average was $1.47 \pm 1.25 \times 10^{6}$ cells $1^{-1}$.

Microphytoplankton was most numerous in spring in both areas. More than one high value was found, and the highest, at WNA in March 1993, was $62.33 \times 10^{6}{\text { cells } 1^{-1}}^{-1}$ (Fig. 7). The average abundance was $1.07 \pm 4.11 \times 10^{6}$ cells $1^{-1}$. Microphytoplankton cell numbers were lower in ENA. The maximum was $2.37 \times 10^{6}$ cells $1^{-1}$ in March 1992 , and the average $0.13 \pm 0.33 \times 10^{6}$ cells $1^{-1}$.

\section{Zooplankton}

Although there were generally high numbers of nonloricate ciliates and tintinnids, copepod nauplii accounted for the highest microzooplankton abundance: $31 \%$ at WNA,
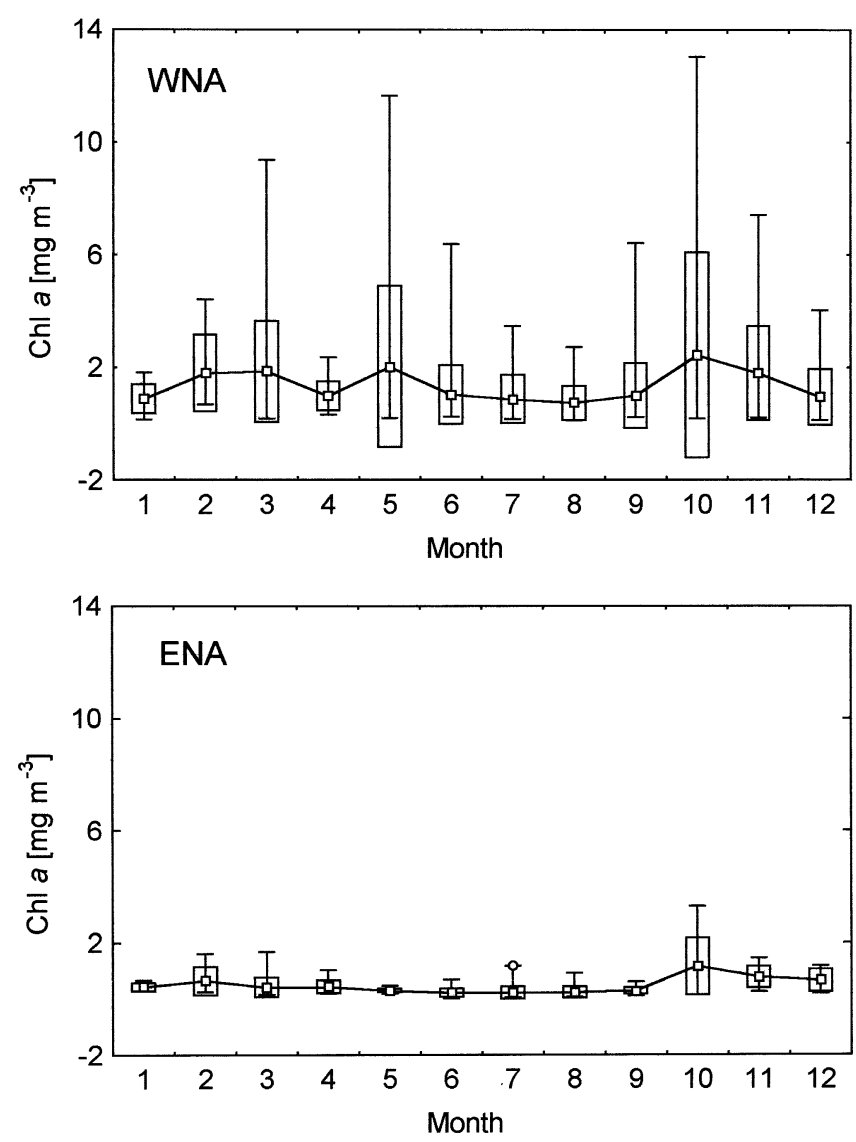

Fig. 5 Box plot of Chl- $a$ concentrations in the northern Adriatic Sea during 1990-1993. Middle tiny squares and line indicate mean values, box presents standard deviations, whisker min-max values

and 35\% at ENA. The mean composition of nonloricate ciliates, tintinnids, copepodites, and small adult copepods was generally similar at both stations: $35 \%, 24 \%, 7 \%$, and $3 \%$ at WNA; and $34 \%, 23 \%, 6 \%$, and $2 \%$ at ENA. Oithona nana and Oncaea spp. were the most numerous small adult copepods.

High abundances of meso-fraction copepods were found in all seasons, especially in spring and summer. At WNA these ranged between 146 and 9,137 ind. $\mathrm{m}^{-3}$ $\left(2,345 \pm 1,739\right.$ ind. $\left.\mathrm{m}^{-3}\right)$; at ENA between $199-6,729$ ind. $\mathrm{m}^{-3}\left(2,034 \pm 1,721\right.$ ind. $\left.\mathrm{m}^{-3}\right)$. The most numerous species was Paracalanus parvus, followed by Acartia clausi, Temora longicornis, Oithona similis, Pseudocalnus elongatus, Calanus helgolandicus (especially at the end of winter and during spring at WNA), Temora stylifera, and Oithona plumifera (summer-fall species).

At ENA, copepods characteristic of the surface layer of the open sea were noted in a higher number during fall: Nannocalanus minor, Calocalanus pavo, Clausocalanus arcuicornis, $\mathrm{Cl}$. jobei, Cl. furcatus, Ctenocalanus vanus, Temora stylifera, and Oithona plumifera.

In both areas, increased total nauplii densities were found in the May-June period, and the highest abundance in August and September, with maximum values more than 400 ind. $~^{-1}$ (Fig. 8). The quadrennial average was 

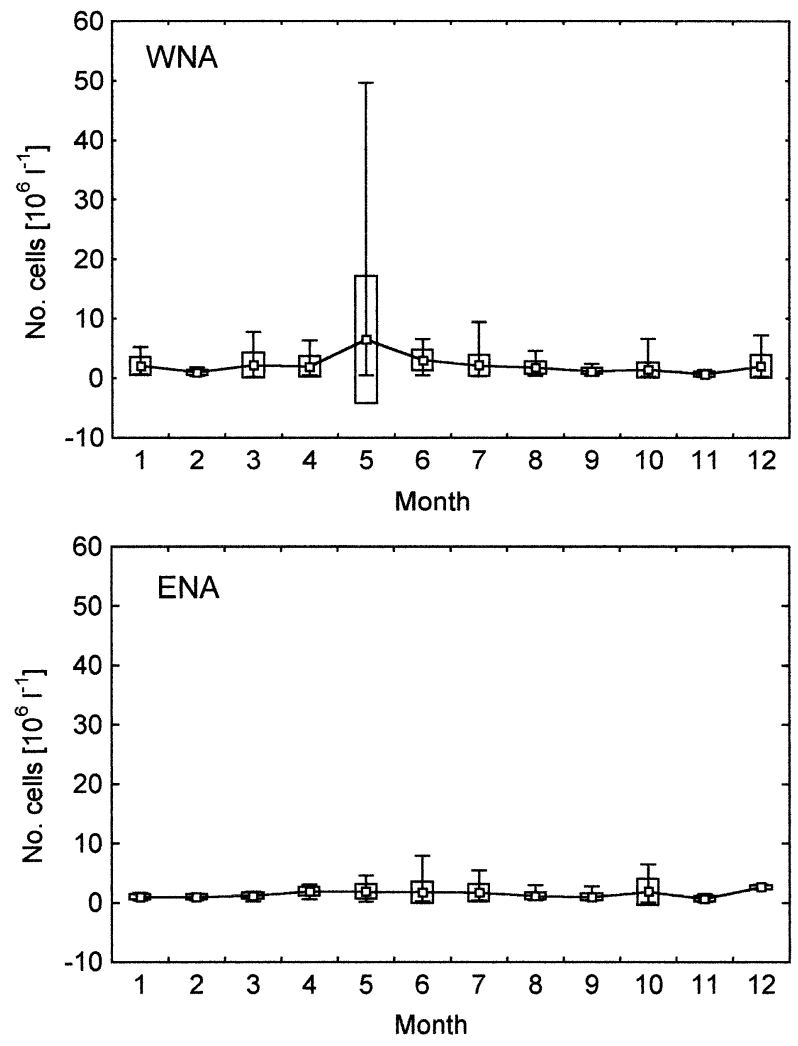

Fig. 6 Box plot of the numerical abundances of nanophytoplankton in the northern Adriatic Sea during 1990-1993. Middle tiny squares and line indicate mean values, box presents standard deviations, whisker min-max values

$48 \pm 60.68$ ind. $1^{-1}$ at WNA, and $47.67 \pm 58.35$ ind. $1^{-1}$ at ENA.

No significant difference was found between naupliar abundance at WNA and ENA (Table 1). Significantly

Table 1 Comparison of WNA and ENA sampling stations with respect to chlorophyll $a$ concentrations, bacteria, cyanobacteria, phytoplankton and nauplii abundances (Mann-Whitney test)

\begin{tabular}{lcl}
\hline Taxon & Probability & Sequence of abundance \\
\hline Bacteria & $<0.001$ & WNA $>$ ENA \\
Cyanobacteria & 0.024 & WNA $>$ ENA \\
Chlorophyll $a$ & $<0.001$ & WNA $>$ ENA \\
Nanophytoplankton & $<0.001$ & WNA $>$ ENA \\
Microphytoplankton & $<0.001$ & WNA $>$ ENA \\
Nauplii (total) & 0.059 & WNA=ENA \\
\hline
\end{tabular}
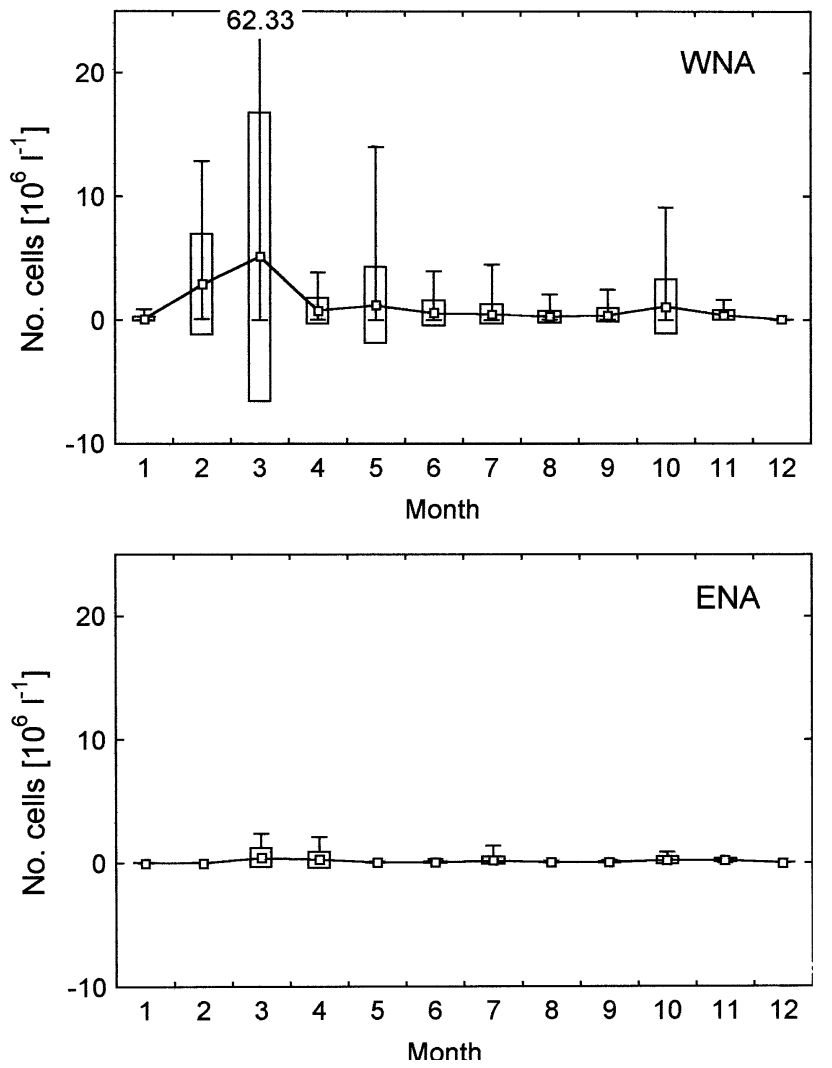

Fig. 7 Box plot of the numerical abundances of microphytoplankton in the northern Adriatic Sea during 1990-1993. Middle tiny squares and line indicate mean values, box presents standard deviations, whisker min-max values

higher nauplii densities were found in the surface layer at WNA (Table 2).

The highest values, 40-50 ind. $1^{-1}$, were recorded in August and September for the first three nauplii fractions (NS1-NS3) at both survey areas (Fig. 9). These fractions were considerably more abundant than the others. Minor peaks in May were noted for NS2 and NS3, too. The highest mean values for NS4 did not exceed 15 ind. $1^{-1}$. Several other peaks occurred throughout the year, with no clear evidence of seasonality. Pronounced peaks of the NS5 fraction were found in February at WNA, and in October at ENA.

The average number of anchovy eggs for MaySeptember was $14.04 \pm 14.66 \mathrm{eggs} / \mathrm{m}^{3}$ at WNA, and $10.90 \pm 7.88 \mathrm{eggs} / \mathrm{m}^{3}$ at ENA. The maxima were 53
Table 2 Comparison of surface $(S)$ and bottom layers $(B)$ at WNA and WNA sampling stations with respect to chlorophyll- $a$ concentrations, bacteria, cyanobacteria, phytoplankton and nauplii abundance (MannWhitney test)

\begin{tabular}{|c|c|c|c|c|}
\hline \multirow[t]{2}{*}{ Taxon } & \multicolumn{2}{|l|}{ Probability } & \multicolumn{2}{|c|}{ Sequence of abundance } \\
\hline & WNA stations & ENA stations & WNA stations & ENA stations \\
\hline Bacteria & 0.003 & 0.891 & $\mathrm{~S}>\mathrm{B}$ & \\
\hline Cyanobacteria & 0.389 & 0.934 & & \\
\hline Chlorophyll $a$ & $<0.001$ & 0.042 & $\mathrm{~S}>\mathrm{B}$ & \\
\hline Nanophytoplankton & $<0.001$ & 0.065 & $\mathrm{~S}>\mathrm{B}$ & \\
\hline Microphytoplankton & $<0.001$ & 0.003 & $\mathrm{~S}>\mathrm{B}$ & $\mathrm{S}>\mathrm{B}$ \\
\hline Nauplii (total) & $<0.001$ & 0.283 & $\mathrm{~S}>\mathrm{B}$ & \\
\hline
\end{tabular}



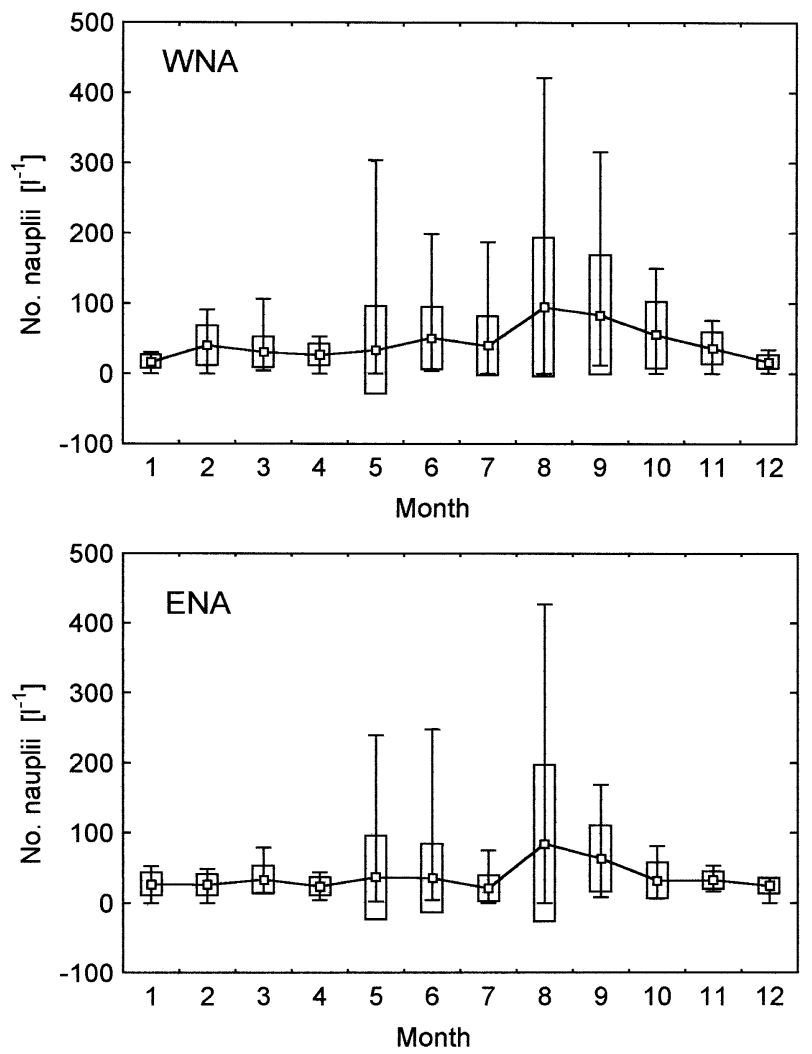

Fig. 8 Box plot of the numerical abundances of nauplii in the northern Adriatic Sea during 1990-1993. Middle tiny squares and line indicate mean values, box presents standard deviations, whisker min-max values

eggs $/ \mathrm{m}^{3}$ in May and August 1992 at WNA, and 26 eggs/ $\mathrm{m}^{3}$ in June at ENA.

\section{Interrelationships between parameters}

Significantly higher concentrations of Chl- $a$, picoplankton, and phytoplankton were noted at WNA (Table 1). The NS5 fraction was particularly numerous only at WNA. Higher concentrations were found in the surface layer at WNA for: Chl- $a$, bacteria, nanophytoplankton, total nauplii numbers, and the NS3 and NS4 nauplii fractions. This is significantly different from bottom-layer samples (Table 2). A marked number of microphytoplankton cells were found in the surface layers of both areas. The NS5 fraction showed a trend for near-bottom aggregations.

The relationship between nauplii fractions and other parameters was analyzed by multiple regression (Table 3 ). Coefficients of correlation higher than 0.50 were noted at WNA for all fractions $(r=0.52-0.65)$, while at ENA only for NS5 $(r=0.68)$.

Temperature significantly correlated with all fractions at WNA, and only with NS1 and NS5 at ENA. The influence of temperature on NS5 was negative in both areas. Relationships between nauplii fractions and other

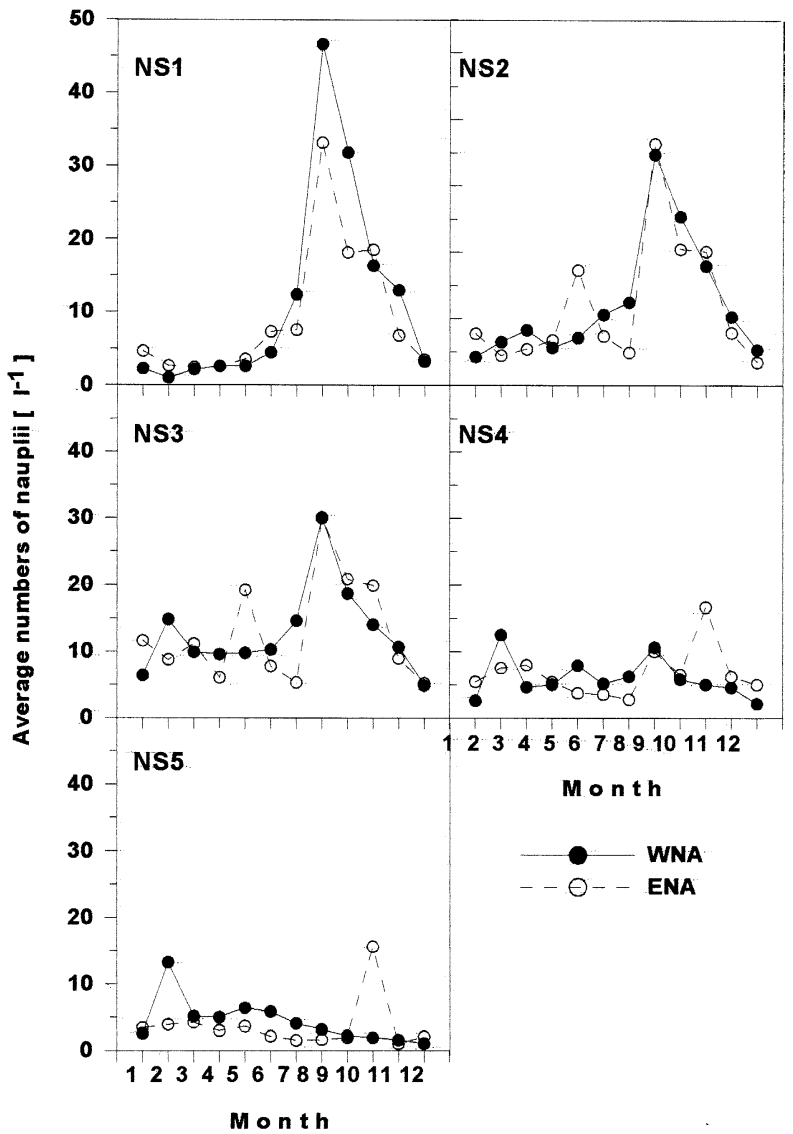

Fig. 9 Average numbers of nauplii of different size fractions (NS1$N S 5)$ in the western (WNA) and eastern (ENA) part of the northern Adriatic Sea during 1990-1993

parameters were more regular at WNA. Bacterioplankton correlated only with NS1, while cyanobacteria correlated with the larger NS3-NS5 fractions. Nanophytoplankton numbers correlated positively and significantly with NS3-NS5 fractions, while microphytoplankton correlated with NS4 and NS5 fractions.

A comparison of the mean number of nauplii with the number of anchovy eggs collected with $250 \mu \mathrm{m}$ mesh plankton net from May to November showed positive correlations: $n=43, r=0.69, P<0.001$ at WNA; $n=41, r=60$, $P<0.01$ at ENA. No differences in the number of anchovy eggs were noted between WNA and ENA.

\section{Discussion}

The northern Adriatic marine ecosystem is influenced by inputs of freshwater, nutrients, and pollutants, mainly from the Po River (Degobbis et al. 2000). Owing to the relatively shallow setting of this area, variations in discharge can have dramatic effects on the composition of the plankton. For example, ciliated protozoans are traditionally the most abundant component of the northern Adriatic microzooplankton (Coats and Revelante 1999); at times, their biomass exceeds that of micrometazoans 
Table 3 Results of multiple correlation analysis, for WNA and ENA, between the abundance of different nauplii size fractions (NS1-NS5), abiotic and biotic parameters (significant $\beta$ coefficients are marked by an asterisk)

\begin{tabular}{lccccc}
\hline WNA & NS1 & NS2 & NS3 & NS4 & NS5 \\
\hline Multiple correlation coefficient & 0.65 & 0.59 & 0.59 & 0.65 & 0.52 \\
Temperature & $0.57^{*}$ & $0.55^{*}$ & $0.41^{*}$ & $0.32^{*}$ & $-0.30^{*}$ \\
Salinity & 0.10 & 0.08 & 0.10 & 0.03 & 0.08 \\
Bacteria & $0.23^{*}$ & 0.08 & 0.10 & 0.18 & 0.12 \\
Cyanobacteria & -0.02 & 0.00 & $0.34^{*}$ & $0.43^{*}$ & $0.27^{*}$ \\
Chlorophyll $a$ & -0.13 & -0.07 & 0.01 & 0.02 & 0.04 \\
Nanophytoplankton & -0.06 & 0.07 & $0.21^{*}$ & $0.35^{*}$ & $0.27^{*}$ \\
Microphytoplankton & 0.08 & 0.04 & 0.15 & $0.21^{*}$ & $0.21^{*}$ \\
ENA & NS1 & NS2 & NS3 & NS4 & NS5 \\
Multiple correlation coefficient & 0.46 & 0.33 & 0.33 & 0.46 & 0.68 \\
Temperature & $0.36^{*}$ & 0.12 & 0.00 & -0.18 & $-0.57^{*}$ \\
Salinity & -0.03 & 0.04 & 0.07 & 0.03 & 0.05 \\
Bacteria & 0.19 & 0.22 & 0.20 & 0.20 & 0.11 \\
Cyanobacteria & 0.07 & 0.03 & -0.02 & 0.01 & $0.31^{*}$ \\
Chlorophyll $a$ & -0.06 & -0.07 & -0.11 & -0.21 & -0.13 \\
Nanophytoplankton & 0.03 & 0.20 & $0.34^{*}$ & 0.20 & 0.11 \\
Microphytoplankton & -0.02 & -0.07 & -0.10 & -0.02 & -0.02 \\
\hline
\end{tabular}

(Kršinić 1995). During 1990-1993, however, the Po River discharge was well below the 50-year average, and the concentration of ciliates was unusually low. Nauplii thus became the dominant group of the microzooplankton community.

Copepod nauplii density was generally high at the end of spring, and highest in midsummer. Densities found in the present study - from 200 to 450 ind $1^{-3}$ - are among the highest reported for coastal marine environments (e.g. Beers et al. 1980; Liang and Uye 1996a, 1996b; Incze et al. 1996; Zhang and Wang 2000; Godhantaraman and Uye 2001). One notable exception is a Mexican Bay that had more than 1,000 ind. $1^{-1}$ (Dagg et al. 1987; Dagg and Whitledge 1991).

During most of the year the smallest naupliar fractions were dominant. Their high summer abundance corresponded with the high numbers of anchovy eggs found during the same period. A major portion of these copepods were small cyclopoids, the most abundant metazoans in all parts of the world ocean (Paffenhöfer 1993; Gallienne and Robins 2001).

Among the many environmental factors that affect nauplii growth and abundance, temperature and food have received most attention (e.g. Revelante at al. 1985; Godhantaraman and Uye 2001; Rey et al. 2001). All nauplii fractions in WNA had a significant correlation with temperature; in ENA only NS1 and NS5 had significant correlations. The correlation between temperature and the NS5 fraction was negative in both areas. This results from the fact that higher numbers of this largest size category occurred near the bottom, where temperatures were lower. High values were recorded in winter and spring in WNA, and during fall in ENA. The same pattern was found for the larger calanoid copepods $(1-3 \mathrm{~mm})$ in both areas.

The NS1 fraction in WNA correlated positively with bacteria abundance. This suggests that bacteria may be an important food for the first developmental stages of the ubiquitous small cyclopoids and poecilostomatoids. According to some reports, cyclopoid and poecilostomatoid nauplii start to feed immediately after hatching (Uchima and Hirano 1986; Paffenhöfer 1993), unlike calanoid nauplii, which begin to feed only in the second and third naupliar stages (see, e.g.. Peterson 2001). Roff et al. (1995) calculated that daily food requirements of nauplii can be met by a diet of bacteria and picoplankton, but not by nano- and net-phytoplankton. Moreover, significant regression coefficients between cyanobacteria (a larger size class of picoplankton) and the NS3, NS4, and NS5 fractions were noted.

Significant correlations were not found between the smaller size classes (NS1-NS3) and either Chl- $a$ or nanophytoplankton, but high values of nauplii during the summer corresponded with the lowest values of Chl- $a$ and a lower abundance of nanophytoplankton. This may result from intense grazing by the numerous adult Oithona nana found during this period (Kršinić 1995), followed by proliferation of its nauplii.

The density of larger nauplii (NS3-NS5) in WNA correlated positively with nanophytoplankton. This suggests the importance of these small phytoplankton cells in naupliar development. There was a less significant correlation with microphytoplanton cells and the largest nauplii (NS4-NS5).

Biological factors correlated strongly with the abundance of naupliar sizes only in WNA, although there were especially large variations in phytoplankton numbers in these area. One reason for this might be the influence of oligotrophic, high-salinity, well-oxygenated mid-Adriatic waters in the eastern sector of the northern Adriatic (Orlić et al. 1992). Depending on the severity and persistence of meteorological conditions, the water column in WNA is generally more strongly stratified, and the highest values for most of the estimated parameters were noted in the surface layer. Seasonal variations in phytoplankton in ENA were notably lower. Total nauplii abundance, however, was similar in both areas, as were the abundances of the various naupliar size fractions.

Nauplii filtration and ingestion rates are well described by saturation kinetics (Price and Paffenhofer 1986). At the maximum Chl- $a$ concentrations and phytoplankton abundances observed during this study, it may be 
speculated that nauplii were feeding at saturation levels, and so were not food-limited. Thus, available food concentrations and cell sizes would not seem to limit nauplii growth in either study area. Similarly, Turner et al. (1999), working in the western part of the northern Adriatic, concluded that zooplankton grazing had a minimal impact on the phytoplankton community; instead, they found phytoplankton growth to continue unabated until nutrients were exhausted.

Drawing conclusions about the dynamic behavior of ecosystems from discrete samples taken at time intervals longer than the characteristic times of key processes is fraught with interpretation problems. The data presented here nevertheless suggest where limited sampling resources should be deployed to describe more confidently the functional role of copepod nauplii in the northern Adriatic plankton community.

Acknowledgements We express our gratitude to Dr. Frano Kršinić for providing the microzooplankton samples. We thank Dr. Nick Staresinic and Dr. Adam Benović for constructive criticism and comments on the manuscript. The Ministry of Science and Technology of Croatia supported this research.

\section{References}

Beers JR, Reid FMH, Stewart GL (1980) Microplankton population structure in southern California nearshore waters in late spring. Mar Biol 60:209-226

Benović A, Fonda-Umani S, Malej A, Specchi M (1984) Net zooplankton biomass of the Adriatic Sea. Mar Biol 79:209-218

Benović A, Lučić D, Onofri V (2000) Does change in an Adriatic hydromedusan fauna indicate an early phase of marine ecosystem destruction? P S Z N Mar Ecol 21:221-231

Boicourt WC, Kuzmić M, Hopkins TS (1999) The inland sea: circulation of Chesapeake Bay and the Northern Adriatic. In: Malone TC, Malej A, Harding LW, Smodlaka N, Turner RE (eds) Ecosystems at the land-sea margin: drainage basin to coastal sea. (Coastal and Estuarine Studies 55) American Geophysical Union, Washington, D.C., pp 81-129

Calbet A, Garrido S, Saiz E, Alcaraz M, Duarte CM (2001) Annual zooplankton succession in coastal NW Mediterranean waters: the importance of the smaller size fractions. J Plankton Res 23:319-331

Coats DW, Revelante N (1999) Distributions and trophic implications of microzooplankton. In: Malone TC, Malej A, Harding LW, Smodlaka N, Turner RE (eds) Ecosystems at the land-sea margin: drainage basin to coastal sea. (Coastal and Estuarine Studies 55) American Geophysical Union, Washington, D.C., pp 207-239

Conway DVP, Coombs SH, Smith C (1998) Feeding of anchovy Engraulis encrasicolus larvae in the northwestern Adriatic Sea in response to changing hydrobiological conditions. Mar Ecol Prog Ser 175:35-49

Coombs SH, Giovanardi O, Conway DVP, Manzueto L, Halliday N, Barrett C (1997) The distribution of eggs and larvae of anchovy (Engraulis encrasicolus) in relation to hydrography and food availability in the outflow of the river Po. Acta Adriat 38:33-47

Ćosović B, Vojvodić V (2000) Mucilage events in the northern Adriatic: search for tools for early warning. In: Požar-Domac A (ed) Responsible coastal zone management: the challenge of the 21st century. Period Biol 102:255-259

Dagg MJ, Whitledge TE (1991) Concentration of copepod nauplii associated with the nutrient-rich plume of the Mississippi River. Cont Shelf Res 11:1409-1423
Dagg MJ, Ortner PB, Al-Yamani F (1987) Winter time distribution and abundance of copepod nauplii in the northern Gulf of Mexico. Fish Bull 86:319-330

Degobbis D, Precali R, Ivancic I, Smodlaka N, Fuks D, Kveder S (2000) Long-term changes in the northern Adriatic ecosystem related to anthropogenic eutrophication. Int $\mathrm{J}$ Environ Pollut 13:495-533

Gallienne CP, Robins DB (2001) Is Oithona the most important copepod in the world's oceans? J Plankton Res 23:1421-1432

Godhantaraman N, Uye S (2001) Geographical variations in abundance, biomass and trophodynamic role of microzooplankton across an inshore-offshore gradient in the inland sea of Japan and adjacent Pacific Ocean. Plankton Biol Ecol 48:1927

Gotsis-Skretas O, Horstmann U, Wiryawan B (2000) Cell size structure of phytoplankton communities in relation to physicochemical parameters and zooplankton in a temperate coastal environment. Arch Fish Mar Res 48:265-282

Hunter JR (1984) Feeding ecology and predation of marine fish larvae. In: Lasker $\mathrm{R}$ (ed) Marine fish larvae: morphology, ecology and relation to fisheries. University of Washington Press, Seattle

Incze LS, Peter AAS, Ainaire T (1996) Distribution of copepod nauplii and turbulence on the southern flank of Georges Bank: implications for feeding by larval cod (Gadus morhua). DeepSea Res II 43:1855-1873

Kršinić F (1995) Changes in the microzooplankton assemblages in the northern Adriatic Sea during 1989 to 1992. J Plankton Res 17:935-953

Last JM (1980) The food of twenty species of fish larvae in the west-central North Sea. (Fisheries Research Technical Report 60) MAFF Directorate of Fisheries Research, Lowestoft

Liang D, Uye S (1996a) Population dynamics and production of the planktonic copepods in a eutrophic inlet of the inland sea of Japan. II. Acartia omori. Mar Biol 125:109-117

Liang D, Uye S (1996b) Population dynamics and production of the planktonic copepods in a eutrophic inlet of the inland sea of Japan. III. Paracalanus sp. Mar Biol 127:219-227

Lonsdale DJ, Cosper EM, Doall M (1996) Effects of zooplankton grazing on phytoplankton size-structure and biomass in the lower Hudson River estuary. Estuaries 19:874-889

Orlić M, Gačić M, La Violette PE (1992) The currents and circulation of the Adriatic sea. Oceanol Acta 15:109-124

Ott JA, Herndl GJ (1995) Gelatinous aggregates in the northern Adriatic Sea. In: Briand F (ed) Les mers tributaries de Méditerranée (Mediterranean tributary seas). (Bulletin de l'Institut océanographique, Monaco 15, CIESM science series 1) CIESM (International Commission for the Scientific Exploration of the Mediterranean Sea, Monaco, pp 133-147

Paffenhöfer GA (1993) On the ecology of marine cyclopoid copepods (Crustacea, Coepoda). J Plankton Res 15:185-211

Park GO, Marshall HG (2000) Estuarine relationships between zooplankton community structure and trophic gradients. J Plankton Res 22:121-135

Peterson WT (2001) Patterns in stage duration and development among marine and freshwater calanoid and cyclopoid copepods: a review of rules, physiological constraints, and evolutionary significance. Hydrobiologia 453/454:91-105

Porter KG, Feig YS (1980) The use of DAPI for identifying and counting aquatic microflora. Limnol Oceanogr 25:943-948

Price JP, Paffenhöfer GA (1986) Effects of concentration on the feeding of a marine copepod in algal monocultures and mixtures. J Plankton Res 8:119-128

Regner S (1985) Ecology of the planktonic stages of the anchovy Engraulis encrasicolus (Linnaeus, 1758) in the central Adriatic. Acta Adriat 26:5-113

Revelante N, Gilmartin M, Smodlaka N (1985) The effects of Po River induced eutrophication on the distribution and community structure of ciliated protozoans and micrometazoan populations in the northern Adriatic sea. J Plankton Res $7: 461-471$ 
Rey C, Harris R, Irigoien X, Head R, Carlotti F (2001) Influence of algal diet on growth and ingestion of Calanus helgolandicus nauplii. Mar Ecol Prog Ser 216:151-165

Roff JC, Turner JT, Webber MK, Hopcroft RR (1995) Bacterivory by tropical copepod nauplii: extent and possible significance. Aquat Microb Ecol 9:165-175

Spiegel M (1972) Theory and problems of statistics. (Schaums' outline series) McGraw Hill, New York

Strickland JDH, Parsons TR (1972) A practical handbook of seawater analysis. Bull Fish Res Bd Can 167:1-311

Takahashi M, Kikuchi K, Hara Y (1985) Importance of picocyanobacteria biomass (unicellular, bluegreen algae) in the phytoplankton population of the coastal waters of Japan. Mar Biol 89:63-69

Turner JT, Tester PA, Lincoln LA, Carlsson P, Grané E (1999) Effects of N:P:Si ratios and zooplankton grazing on phyto- plankton communities in the northern Adriatic Sea. III. Zooplankton populations and grazing. Aquat Microb Ecol 18:67-75

Uchima M, Hirano R (1986) Food of Oithona davisae (Copepoda: Cyclopoida) and effect of food concentration at first feeding on the larval growth. Bull Plankton Soc Jpn 33:21-28

Waugh AE (1952) Elements of statistical methods. McGraw Hill, New York

Zar JH (1974) Biostastistical analysis. Prentice Hall, Englewood Cliffs, N.J.

Zhang W, Wang R (2000) Summertime ciliate and copepod nauplii distributions and micro-zooplankton herbivorous activity in the Laizhou Bay, Bohai Sea, China. Estuar Coast Shelf Sci 51:103114 